\title{
MICROCONTROLLER BASED ISOLATED BOOST DC-DC CONVERTER
}

\author{
Elankurisil.S.A. ${ }^{1}$, Dash.S.S. ${ }^{2}$ \\ ${ }^{1}$ Research Scholar, Sathyabama University, Chennai, India. \\ ${ }^{2}$ SRM University, Chennai, India, \\ E.mail: ${ }^{1}$ saelankurisil@gmail.com, ${ }^{2}$ munu_dash_2k@yahoo.com
}

Abstract

ZVS-PWM isolated boost DC-DC converter. It takes the supply from fuel cell battery at the input side compared to the previous full bridge converter, This half bridge converter to produce the same efficiency. The advantages of the paper is to reduce the number of devices and the mean time to reduce the losses, correspondingly to reduce the space and design cost. The system is simple and easy to operate the entire circle without more additional devices. It is used for medium and high power application. Zero voltage switching is applied in all the inverters. It is achieved the power flow in either direction. The circuit is compact packaging and reduce the losses. The simulation results are of closely agree with the theoretical approach a high efficiency achieved by using a minimal number of electronic devices working in the soft switching mode. It is operated at the frequency of 55 khz.

Terms DC-DC converter, soft switching, bi-directional power flow, conduction, losses, zero current switching and zero voltage switching.

\section{INTRODUCTION}

The necessity of high power isolated bidirectional DC-DC converter can be utilized in wide application from uninterrupted power supplies, battery charging and discharging systems. Most of the DC-DC converters are low power or unidirectional cannot meet the requirements of the above applications.

Nowadays some high power DC-DC converters with soft switching operation has been introduced in the literature [3]-[6]. These converters reduces the switching losses, improved EMl and increased efficiency. These converters are not absolutely achieve the high power density, high reliability and low cost. The circuit has not used the extra devices so there is no bulky and costly implementation. The paper introduces the high power application of isolated boost DC-DC converter. A dual half bridge converter is developed to achieve high power rating. Zero voltage switching is applied in either direction of power flow without using voltage clamping circuit. The circuit is required minimum number of devices. The input DC voltage is $12 \mathrm{~V}$ battery to desire higher voltage (normally 150V-300V) for fuel cell to start. The DC-DC converters recharges the battery from the fuel cell or regenerative braking. In order to increase the efficiency, soft switching is widely used in DC-DC converters. Voltage source converter has high current ripples, while a current source converter requires voltage clamp circuit. The converter is based on dual half bridge topology compared to the dual full bridge topologies, it has half of the component count for the same rating without additional devices. Without no more devices is added in the unified ZVS is achieved in either direction. It has less control at the mean time less accessory than full bridge competitors. All the above features allow efficient power conversion, easy control, light weight and compact packaging. A $1.65 \mathrm{kw}$ prototype of the converter has been built and successfully used under full power. The experimental results of the converters steady state operation confirms the theoretical analysis and simulation results. It is best alternative for full bridge isolated bidirectional DC - DC converter in high power applications and distinct advantages for high power density and low cost applications.Due to their ability to reverse the direction of flow of current and thereby power, while maintaining the voltage polarity at either end unchanged.

\section{CIRCUIT OPERATION \& PRINCIPLE}

The circuit operates bidirectional DC-DC converter is shown in Fig.1. The circuit operates with dual half bridge placed on each side of the isolation transformer when power flows from the low voltage side to the high voltage side, the circuit works in boost mode. When power flows from the high voltage side to the low voltage side the circuit works in buck mode. A dual half bridge is used instead of dual full bridge at the same output power. 
1. The dual half bridge produces the same output power as the dual full bridge.

2. The dual half bridge function uses only half as many devices as the full bridge function.

3. The L.V. Side twice that of the input voltage (12v). The block of fuel cell power bus and energy management system. The low voltage bus is $12 \mathrm{~V}$ battery and the high voltage bus is the fuel cell voltage is $150 \mathrm{~V}$ to $300 \mathrm{~V}$. The circuit consists of an inductor $L_{D C}$ on the battery side.

Fig. 1 shows block diagram of fuel cell powerbus and energy amanagement system. The low voltage bus is $12 \mathrm{~V}$ battery and the high voltage bus is the fuel cell voltage $150-300 \mathrm{~V}$

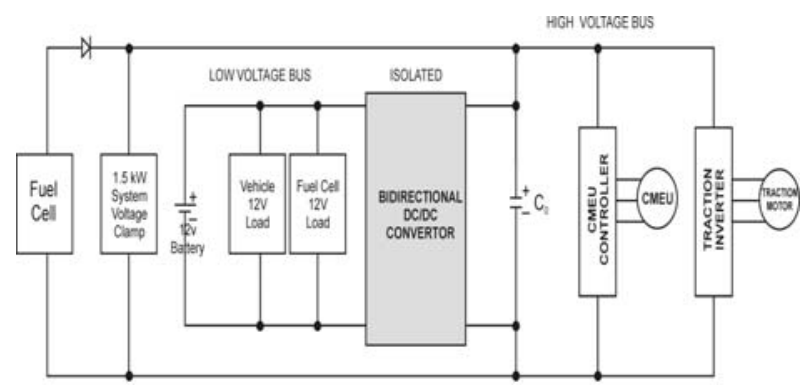

Fig. 1 Block diagram of fuel cell

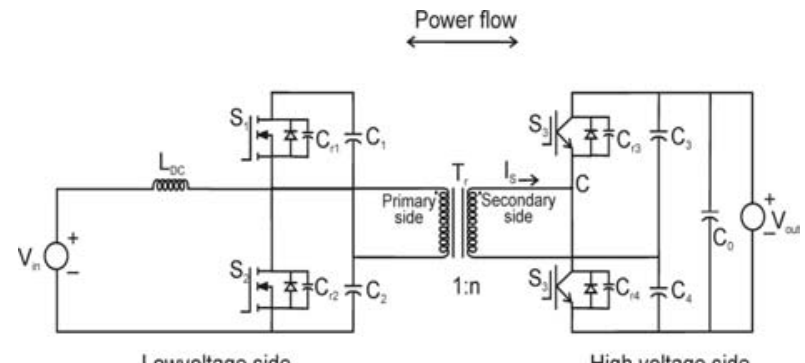

Fig. 2. Soft switched bidirectional half-bridge $d c-d c$ converter

The voltage source is connected in series with the $L_{D C}$ in this form the circuit leads the free from ripple. When the tow switches is provided on either side of the main transformer.

In each switching circuit a small capacitor is connected in parallel to act as a soft switching. When the power flows from low voltage side to high voltage side the circuit works in a boost mode. When the power flows from high voltage side to low voltage side the circuit works in a buck mode.

The converter was developed to improve some characteristic of cuk converter as 1. Isolation, 2. Soft switching, 3. Active voltage clamping.

The leakage inductance of the transformer is utilized as an interface and energy transfer element between the two voltage-source half bridge inverters: LVS and HVS half bridges. Fig. 3 shows the energy transfer principle [4]. The two voltage-source half bridge inverters: LVS and HVS half bridges, each generates a square-wave voltage applied to the primary and secondary of the transformer, respectively. The amount of power transferred is determined by the phase shift of the two square-wave voltages. The current waveform is determined by the phase shift and voltage relationships $\left(V_{1}\right.$ and $\left.V_{3}\right)$ and $\left(V_{2}\right.$ and $\left.V_{4}\right)$. The optimum case would be $\left(V_{1}=V_{3}\right)$ and $\left(V_{2}=V_{4}\right)$. to minimize the peak current. Detailed analysis will be given in Section IV. However, it should be noted here that the two half bridges could have a synchronized duty cycle control rather than $50 \%$. When the duty cycle is $50 \%$, we obtain the easiest and most traditional case of $\phi_{2}=\pi, V_{1}=V_{2}$ and $V_{3}=V_{4}$. This paper focuses on the $50 \%$ duty cycle case

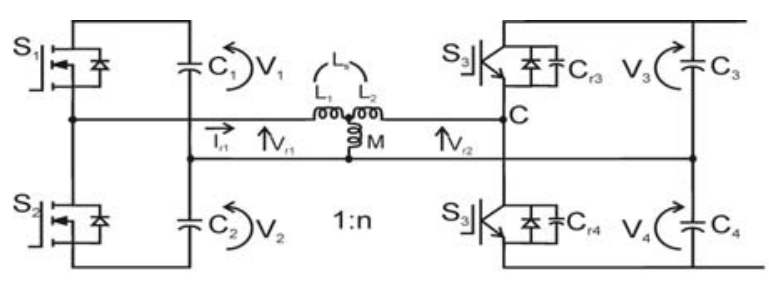

Fig. 3(a) simplified equivalent circuit referred to the primary.

The use of the dual half-bridge topology instead of a dual full-bridge configuration can be justified as follows.

A comparison of total device rating (TDR) in full bridge and half bridge can be made as shown in Fig. 4 . The full bridge is used to produce a high-frequency square-wave $\left(+V_{D C}\right.$ and $\left.+V_{D C}\right)$ voltage. Each switching device in the full bridge is subject to a voltage 
stress equal to the $\mathrm{DC}$-input voltage $V_{\mathrm{DC}}$, and the current stress is equal to the load current $\left(I_{A C}\right)$.

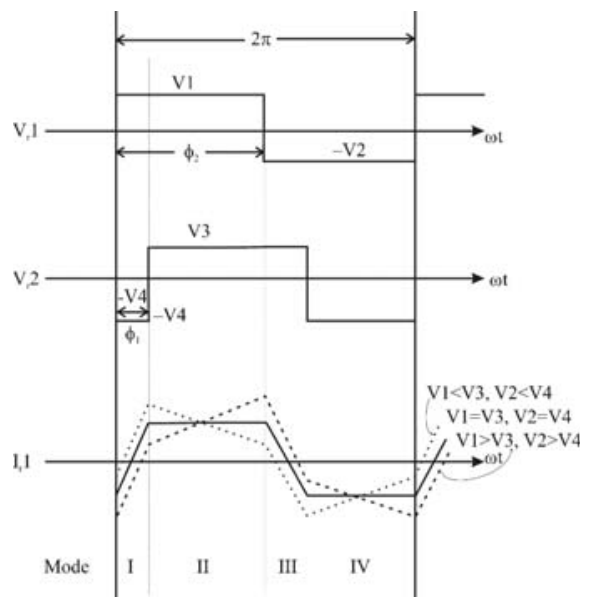

Fig.3b - Idealized voltage and current waveforms of transformer, Note that $V_{3}$ and $V_{4}$ are the values after referred (a factor of $1 / n$ ) to the primary.

The TDR of the full bridge is calculated as $\mathrm{TDR}_{\mathrm{F}}=\mathrm{V}_{\mathrm{DC}} \cdot \mathrm{I}_{\mathrm{AC}}$. (4 devices) $=4 . P_{0}$, where $\mathrm{P}_{0}$ is the output power. The LVS half bridge in the proposed converter (Fig. 2) boosts the DC-rail voltage to twice the $\mathrm{DC}$-input voltage $\left(2 \mathrm{~V}_{\mathrm{DC}}\right)$ and generates a same high-frequency square-wave $\left(+V_{D C}\right.$ and $\left.-V_{D C}\right)$ voltage with when operated at $50 \%$ duty cycle. Therefore, for the half bridge in Fig. 4, each switching device's voltage stress is twice the dc input voltage $\left(2 V_{D C}\right)$, and the current stress is still the load current $\left(\mathrm{I}_{\mathrm{AC}}\right)$. Similarly, the TDR of the half-bridge can be calculated as $\operatorname{TDR}_{\mathrm{F}}=\left(2 \mathrm{~V}_{\mathrm{DC}}\right) \cdot \mathrm{I}_{\mathrm{AC}} \cdot(2$ devices $)=4 \cdot \mathrm{P}_{0}$, devices, where $P_{0}$ is again the output power.

The conclusions can be made as follows.

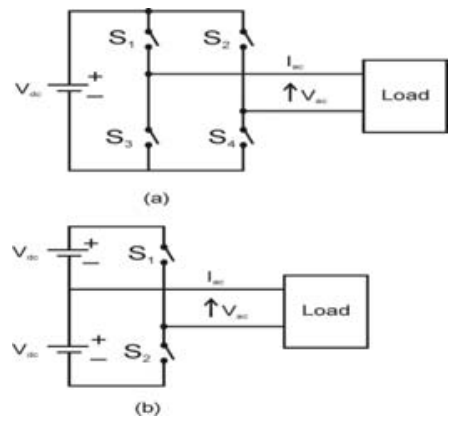

Fig. 4 - comparison of idealized voltage and current waveforms of transformer, Note that $V_{3}$ and $V_{4}$ are the values after referred (a factor of $1 / n$ ) to the primary.
1. The total device rating is the same for the dual half bridge topology and the dual full bridge, for the same output power.

2. Although the devices of the half-bridge are subject to twice the dc input voltage, this is an advantage in EV/HEV and fuel cell applications, because the $\mathrm{dc}$ input voltage is very low $(12 \mathrm{~V}$ battery).

3. The dual half bridge topology uses only half the number of devices as the full-bridge topology.

The major drawback of the half bridge is the split dc capacitors that have to handle the full load current. For the intended application, high current electrolytic capacitors in conjunction with high frequency polypropylene capacitors are used. The other advantages of the proposed circuit are

1. the LVS half bridge produces a relatively ripple-free dc current that is desirable and friendly to the low-voltage source (fuel cell or battery);

2. current ratings (stresses) are minimized for the LVS switching devices and transformer thanks to the boost function of the LVS half bridge;

3. the unified soft-switching capabilities in either direction of power flow without additional switching devices are achieved.

This will be described in the following section. The low input ripple current is achieved due to the current source functionality in this converter. Other topologies (e.g., the full bridge) can also operate as current source. However, a relatively large active clamping circuit is needed for such current source full bridge as indicated in [1], [2].

\begin{tabular}{|l|l|}
\hline Step 1 & $\begin{array}{l}\left(\text { before } t_{1}\right) \text { : Circuit steady state. S1 and } \\
\text { D3 are conducting. }\end{array}$ \\
\hline Step 2 & $\begin{array}{l}\left(t_{1}-t_{2}\right): \text { At } t_{1}, S_{1} \text { is turned off } C_{r 1}, C_{R 2} . \\
\text { and } t_{r} \text { begin to resonate, making } V_{C R} \\
\text { across } C_{r 2} \text { fall from } V_{1}+V_{2} \cdot V_{r 1} \text { also } \\
\text { drops from } V_{1} . \text { The rate of change } \\
\text { depends on the magnitude of, which is } \\
\text { the difference between } I_{r 1} \text { and } I_{d 1} \text { at } t_{1} .\end{array}$ \\
\hline
\end{tabular}




\begin{tabular}{|c|c|}
\hline Step 3 & $\begin{array}{l}\left(t_{2}-t_{3}\right) \text { : At } t_{2}, V_{C 12} \text { attempts to overshoot } \\
\text { the negative rail. } D_{2} \text { is therefore forward } \\
\text { biased. During this period, } S_{2} \text { can be } \\
\text { gated on at zero voltage. }\end{array}$ \\
\hline Step 4 & $\begin{array}{l}\left(t_{3}-t_{4}\right) \text { : From } t_{3}, I_{n 1} \text { is less than } I_{d 1} \text {, so } \\
S_{2} \text { begins to transfer current from } \\
D_{2} \cdot I_{n} \text { keeps on decreasing until it is } \\
\text { equal to } 0 \text { at } t_{4} . D_{3} \text { is thereby still } \\
\text { conducting until } t_{4} \text {. }\end{array}$ \\
\hline Step 5 & $\begin{array}{l}\left(t_{4}-t_{5}\right) \text { : From } t_{4} \text { to } t_{5}, I_{n} \text { begins to } \\
\text { change polarity; therefore, current is } \\
\text { commutated from } D_{3} \text { to } S_{3} \text {. }\end{array}$ \\
\hline Step 6 & $\begin{array}{l}\left(t_{5}-t_{6}\right): \text { At } t_{5}, S_{3} \text { is gated to turn off. } \\
C_{13} \text { and } C_{r 4} \text { begin to be charged and } \\
\text { discharged, respectively. The rate of } \\
\text { change of the voltage depends on } I_{r 1} \text { at } \\
t_{5} \text {. }\end{array}$ \\
\hline Step 7 & $\begin{array}{l}\left(t_{6}-t_{7}\right) \text { : At } t_{6} \text {, when } V_{C r 4} \text { attempts to } \\
\text { overshoot the negative rail, } D_{4} \text { is forward } \\
\text { biased. During this period, } S_{4} \text { can be } \\
\text { gated on at any time at zero voltage. }\end{array}$ \\
\hline Step 8. & $\begin{array}{l}\left(t_{7}-t_{8}\right): \text { At } t_{7}, S_{2} \text { is gated off. } C_{r 1}, C_{r 2} \\
\text { and } T_{r} \text { begin to resonant again, making } \\
V_{C r} \text { across } C_{r 1} \text { discharge from } \\
V_{1}+V_{2} \cdot V_{r 1} \text { therefore increases from } \\
-V_{2} \text {. The rate of change now is } \\
\text { decided primarily by the sum of the } \\
\text { magnitude of } I_{d 1} \text { and } I_{r 1} \text {. }\end{array}$ \\
\hline Step 9 & $\begin{array}{l}\left(t_{8}-t_{9}\right): \text { At } t_{8} \text {, when } V_{C r} \text { attempts to } \\
\text { overshoot the positive rail, } D_{1} \text { is forward } \\
\text { biased. } I_{n} \text { increases until it equals } 0 \text { at } \\
t_{9} \text {. During this period, } S_{1} \text { can be gated } \\
\text { on at zero voltage. }\end{array}$ \\
\hline Step 10 & $\begin{array}{l}\left(t_{9}-t_{10}\right) \text { : From } t_{9} \text { to } t_{10}, I_{n} \text { begins to } \\
\text { change its polarity and continues to } \\
\text { increase until it equals } I_{d 1} \text {. The current } \\
\text { is commutated from } D_{4} \text { to } S_{4} \text {. }\end{array}$ \\
\hline
\end{tabular}

\begin{tabular}{|l|l|}
\hline Step 11 & $\begin{array}{l}\left(t_{10}-t_{11}\right): \text { From } t_{10} \text { to } t_{11}, I_{r 1} \text { begins to } \\
\text { exceed } I_{d 1} . \text { The current is transferred } \\
\text { from } D_{1} \text { to } S_{1} .\end{array}$ \\
\hline Step 12 & $\begin{array}{l}\left(t_{11}-t_{12}\right): \text { At } t_{11}, S_{4} \text { is gated to turn off. } \\
C_{13} \text { and } C_{r 4} \text { begin to be charged and } \\
\text { discharged again. The charge/discharge } \\
\text { rate depends mainly on the magnitude } \\
\text { of } I_{n 1} \text { at } t_{11} \text {. }\end{array}$ \\
\hline Step 13 & $\begin{array}{l}\left(t_{12}-t_{13}\right): \text { At } t_{12}, \text { when }\left\{V_{C B 3} \text { attempts to }\right. \\
\text { overshoot the positive rail, } D_{3} \text { is forward } \\
\text { biased. The circuit returns to the original } \\
\text { steady state. During this period }\end{array}$ \\
\hline
\end{tabular}

Commutation in the proposed circuit is similar to the diode-to-switch commutation mode of the ARCP inverter [14], i.e., turn-off of the main conducting device diverts the current to the corresponding resonant capacitors to charge one and discharge the other, resulting in a zero voltage turn-off. The zero voltage turn-on is achieved by gating on the in-coming device while the anti-parallel diode is conducting. However, unlike ARCP inverter, the proposed circuit does not require an auxiliary circuit to achieve soft switching. From Fig. 6, it is clear that the conditions of soft switching in boost mode depend on the magnitude of $I_{n}$ and $I_{d 1}$ at $t_{1}, t_{5}, t_{7}$ and $t_{11}$, respectively. This is summarized as

$$
\left\{\begin{array}{r}
\ln \left(t_{11}\right)>I_{d 1}\left(t_{1}\right) \\
\ln \left(t_{5}\right)<0 \\
\ln \left(t_{7}\right)>I_{d 1}\left(t_{7}\right) \\
\ln \left(t_{11}\right)>0
\end{array}\right.
$$

\section{A. Boost Mode}

It is observed that the rate of change of the voltage of $S_{1}$ and $S_{2}$ at $t_{1}$ is different from that of $t_{7}$. This is because the turn-off currents are different at their switching instants. Similarly, devices $S_{3}$ and $S_{4}$ have different voltage change rates at $t_{5}$ and $t_{7}$. Comparing these four voltage slopes, $\mathrm{dv} / \mathrm{dt}$ at $t_{1}$ and $\mathrm{dv} / \mathrm{dt}$ at $t_{7}$ represents the minimum and maximum, respectively, because the turn-off current is minimum at $t_{1}$ and maximum at $t_{7}$. As a result, the allowable minimum and maximum $d v / d t$ should be designed according to the application requirements. 


\section{B. Buck Mode}

Because of the half-bridge topology of the two sides is symmetrical, the operation principles in buck mode are similar to those in boost mode. Fig. 8 describes one switching cycle in buck mode. Due to the reversed power-flow direction, the phase of $V_{12}$ is leading $V_{r 1}$. In addition, the inductor current $I_{d 1}$ is reversed. The buck mode operation can also be divided into thirteen steps. The description of each step can be analogously inferred and will not be discussed here.

Like boost mode, the soft-switching conditions in buck mode can be derived similarly as

$$
\left\{\begin{array}{r}
\ln \left(t_{1}\right)<0 \\
\ln \left(t_{5}\right)>I_{d 1}\left(t_{5}\right) \\
\ln \left(t_{7}\right)>0 \\
\ln \left(t_{11}\right)<I_{d 1}\left(t_{11}\right)
\end{array}\right.
$$

Software Program (Boost Mode)

ORG $00 \mathrm{H}$

MOV P1, \# OOH

MOV P3, \# OFFH

MOV A, \# OOH

START: MOV A, P3

ANL A, \# 01H

JZ BOOST

MOV P1, \# 05

CALL DELAY

MOV P1, \# OAH

CALL DELAY

SJMP START

BOOST: MOV P1, \# 50H |

CALL DELAY

MOV P1, \#OA OH

CALL DELAY

SJMP START

DELAY: MOV R1, \# 25H

LOOP: NOP

DJNZ R1, LOOP

ret

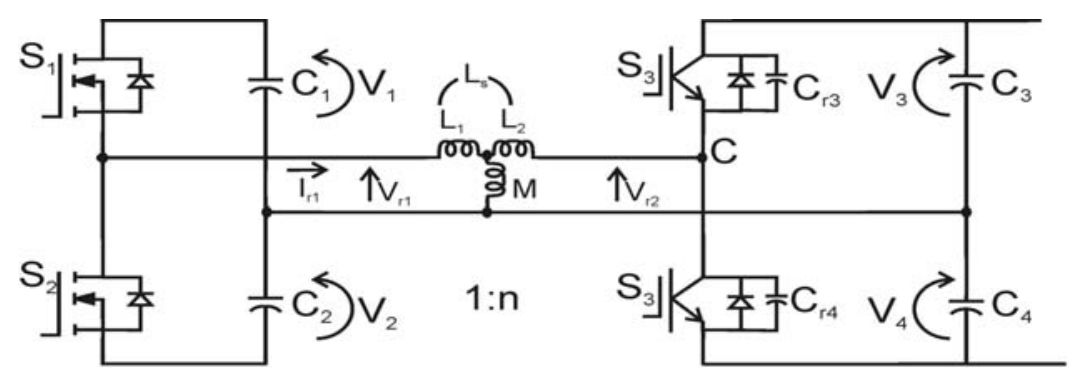

Fig. 5. Wave forms and switching primary referred equivalent circuit.
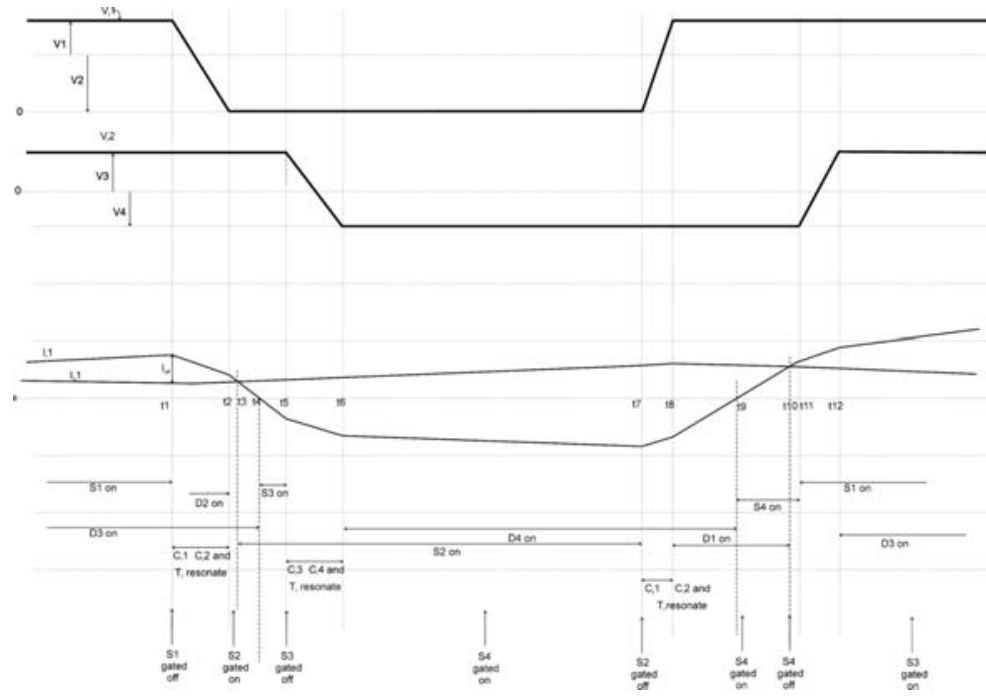

Fig. 6. Wave froms and switching timing of boost mode 


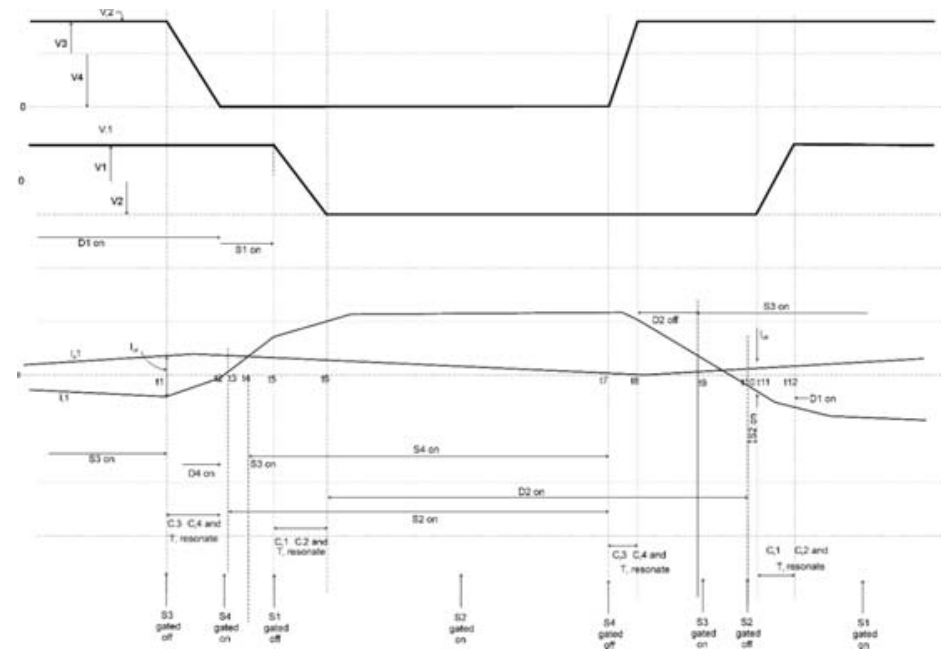

Fig. 7. Wave forms and switching timing of buck mode

\section{Mathematical Analysis of circuits}

This section deals with the calculations of DC-DC converter of ZVS and ZCS. The calculation used to find out the output voltage control region of the converters. The formula is utilized to be calculated the output voltage. $n=N_{1} / N_{2}$

$n=$ turn ratio of transformer

switching frequency $f_{s}=1 / T$ angular switching frequency, $\omega_{s}=2 \pi f_{s}$

$$
V_{0}=V_{\text {in }} / D
$$

\section{SIMULATION VERIFICATION}

DC to DC converter operating in boost mode is shown in Fig 8(a). The scopes are connected to display the driving pulses, primary voltage, secondary voltage and DC output voltage. DC input voltage is applied to the bidirectional $D C$ to $D C$ converter operating in boost mode is shown in Fig $8(b)$.

Driving pulses applied to the MOSFET M1 and $\mathrm{M} 2$ as shown in Fig 8(c). Voltage across the primary is shown in Fig $8(d)$. This stepped up using a step upto 230 volt as shown in Fig 8(e). DC output voltage is shown in Fig $8(\mathrm{f})$.

The current through the transformer is shown in Fig $8(\mathrm{~g})$ and boost mode DC output current is shown in Fig 8(h). The graph is plotted between the input Vs output power is shown in Fig 8(i).
Bidirectional converter is operating in buck mode is shown in Fig 9(a). DC is converted into AC by using the full bridge inverter on the output side is stepped down and converted into DC by using a diode rectifier. The DC input voltage is shown in Fig 9(b). The inverter output

voltage is shown in Fig 9(c). Output voltage is shown in Fig 9(d) and the buck mode DC output current is shown in Fig 9(e). Thus DC to DC converter is capable of transferring power in either Direction. The graph is plotted between the input Vs output power is shown in Fig 9(f).

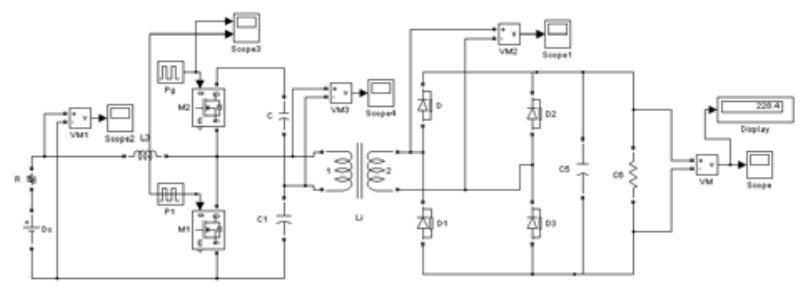

Fig. 8(a) Boost mode circuit diagram

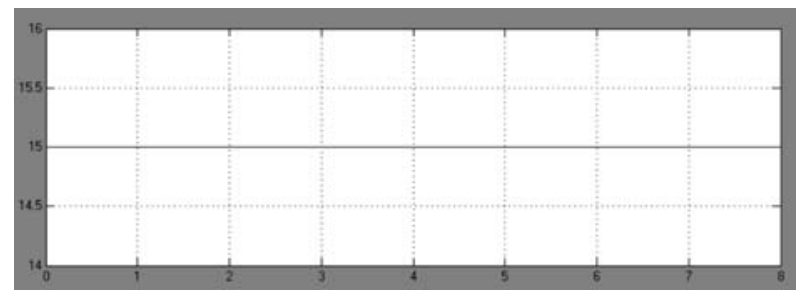

Fig. 8(b) DC Input voltage 


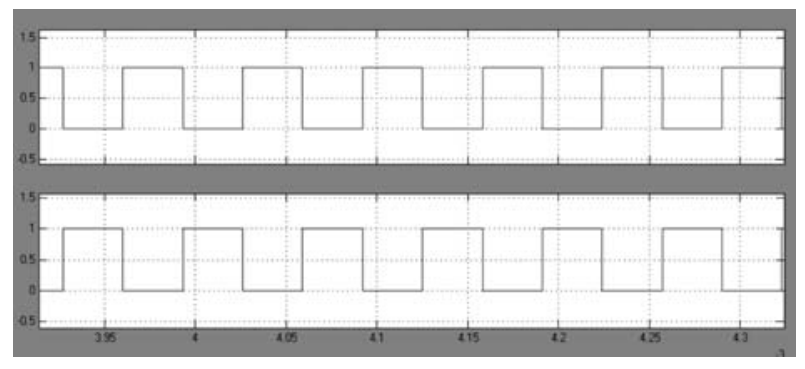

Fig. 8(c) Driving pulses

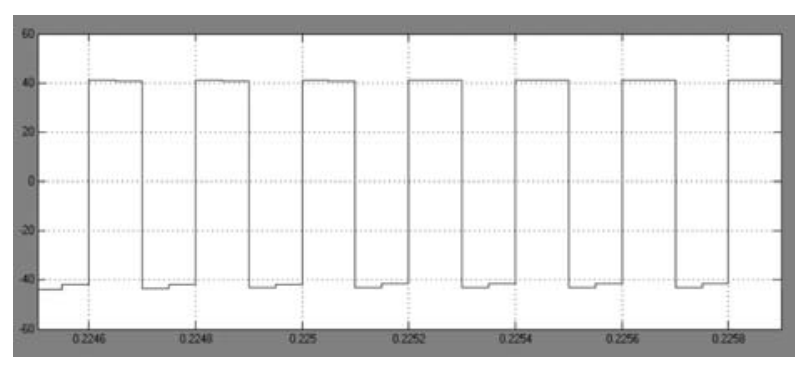

Fig. 8(d) Transformer primary side voltage

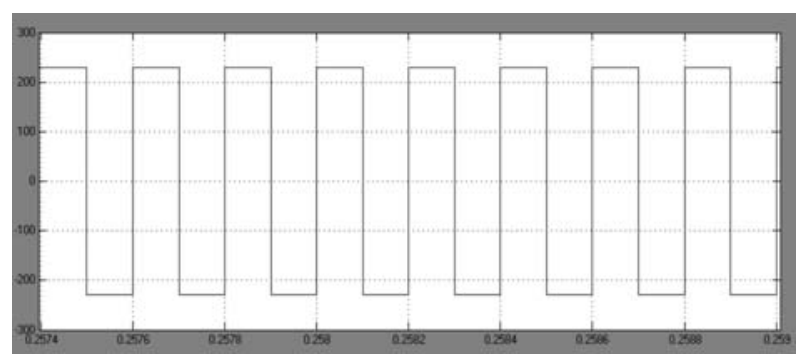

Fig. 8(e) Transformer secondary side voltage

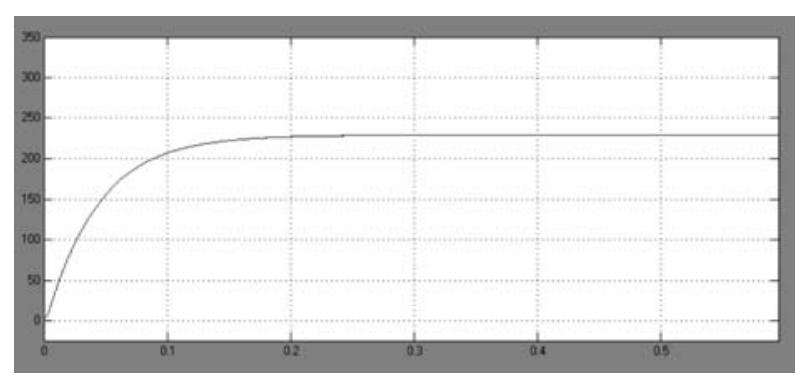

Fig. 8(f) Boost mode DC output voltage

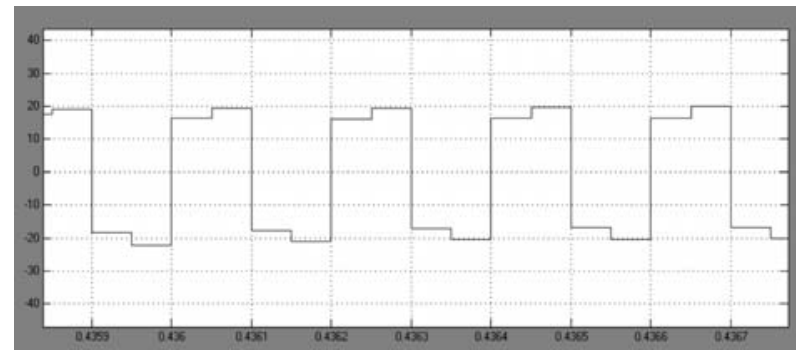

Fig. 8(g) Current through transformer

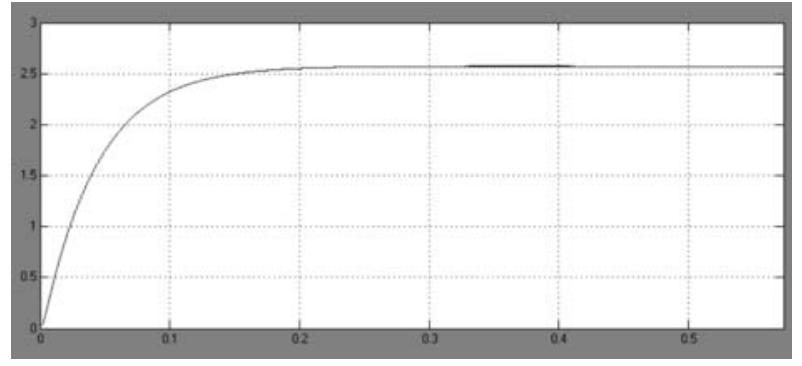

Fig. 8(h) DC output current

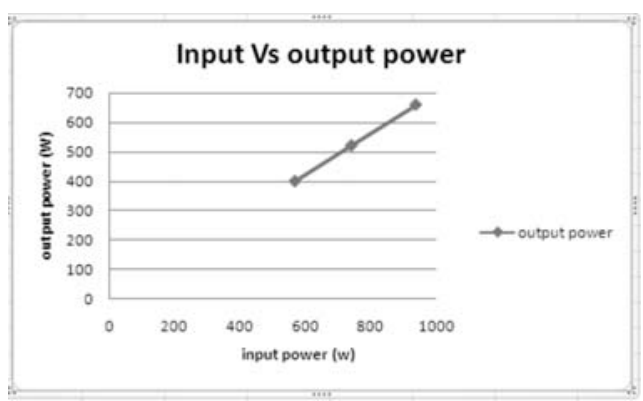

Fig. 8(i) DC input Vs output power

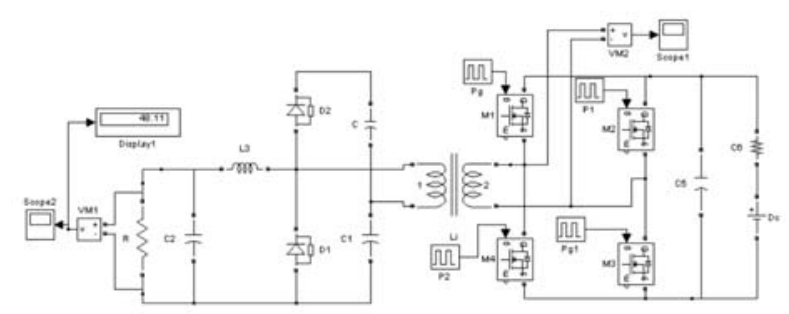

Fig. 9(a) Buck mode circuit diagram

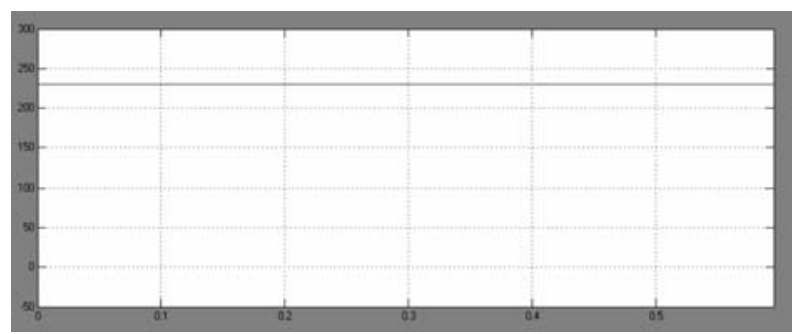

Fig. 9(b) DC input voltage

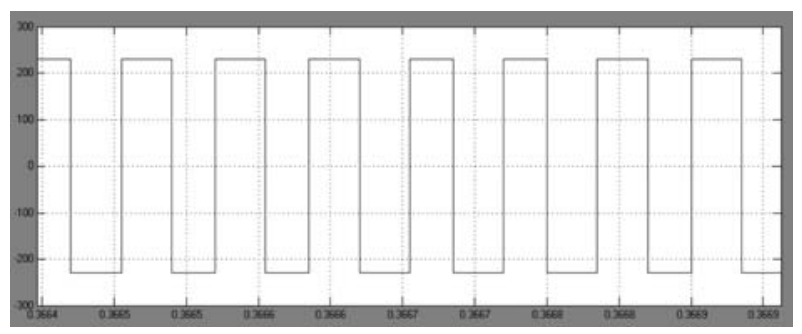

Fig. 9(c) Inverter output 


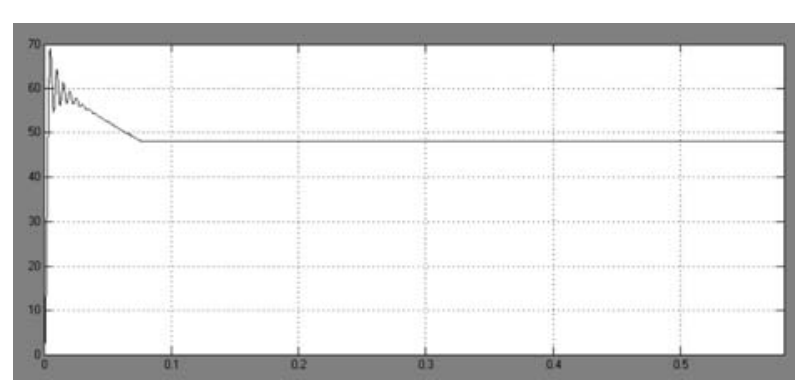

Fig. 9(d) DC output voltage

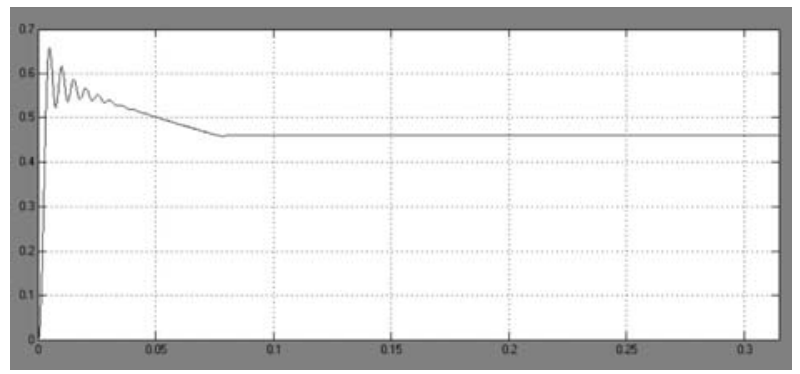

Fig. 9(e) DC output current

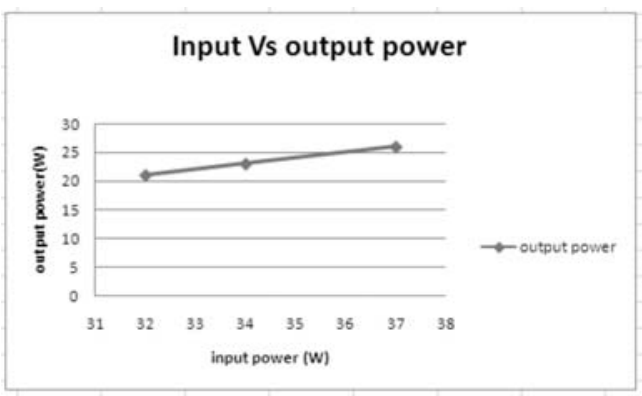

Fig. 9(f) DC input Vs output power

\section{EXPERIMENTAL VERIFICATION}

Laboratory model of bidirectional DC to DC converter is fabricated and tested in the laboratory. Driving pulses required by the MOSFET are generated using 89C51. They are amplified by using driver amplifier. Top view of the hardware is shown in Fig 10(a). The hardware consist of power supply board, driver board and transformer board. The input DC voltage is $24 \mathrm{~V}$ as shown in Fig 10(b). Driving pulses are shown in Fig 10(c). The inverter output voltage is shown in Fig 10(d). The boost output voltage is shown in Fig 10(e). The buck output voltage is shown in Fig 10(f).

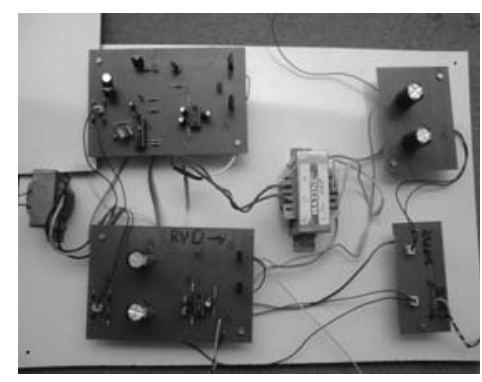

Fig. 10(a) Hardware layout

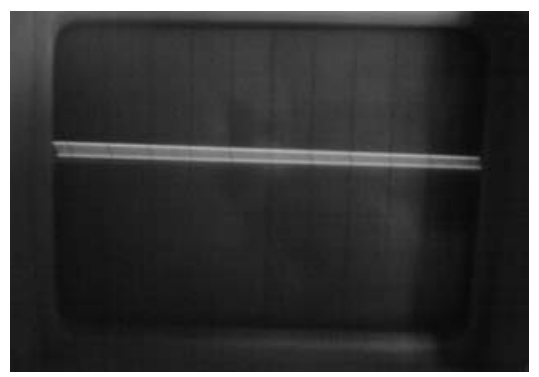

Fig. 10(b) DC input voltage

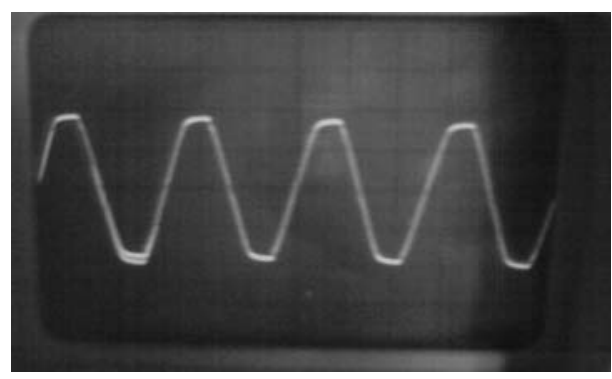

Fig. 10(c) AC input voltage

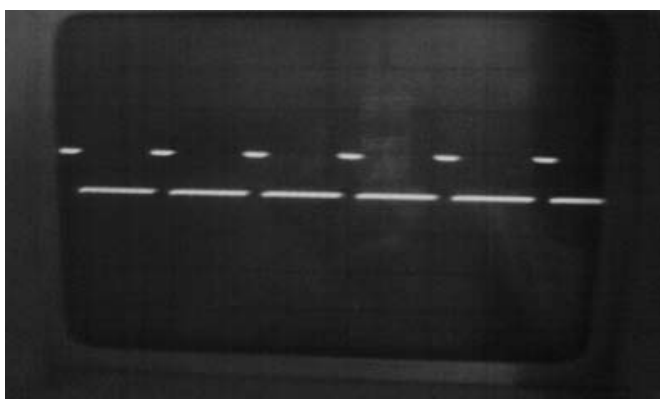

Fig. 10(d) Driving pulses

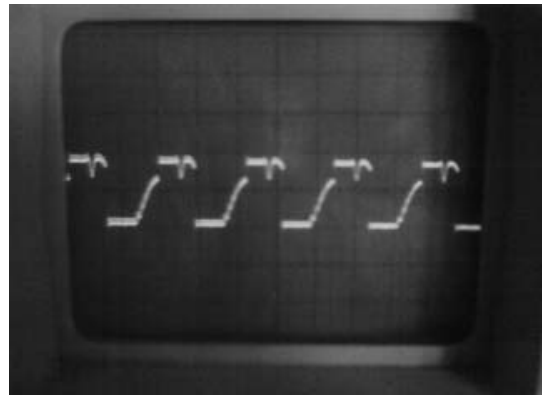

Fig. 10(e) Inverter output voltage 


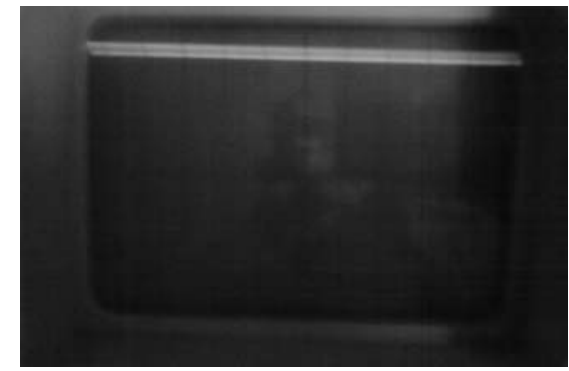

Fig. 10(f) Boost output voltage

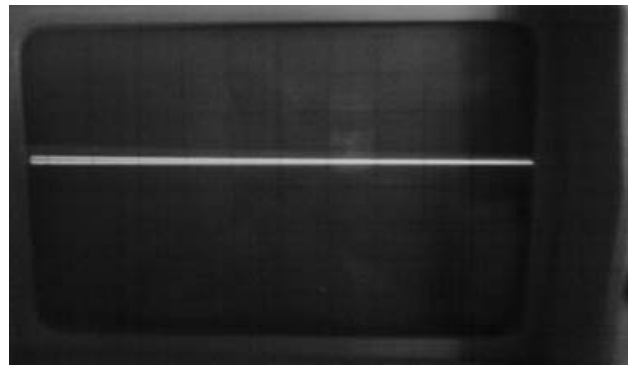

Fig. 10(g) Buck output voltage

\section{CONCLUSION}

This paper presents a soft switched bidirectional DC-DC converter compared with the other bidirectional DC-DC converters. The performance is excellent compared with the full bridge the same output is produced also with the higher efficiency. The total number of components is reduced unidirectional soft switching scheme is achieved without any auxiliary circuit. ZVS is applied in all switches of the device in either direction of power flow. It has low cost, modified design light weight, compact and reliable. The simulation and experimental results are presented. The experimental results are closely agree with the simulation result.

\section{REFERENCES}

[1] F. Z. Peng, H. Li, G.-J. Su, and J. S. Lawler, "A new ZVS bidirectional DC-DC converter for fuel cell and battery application," IEEE Trans. Power Electron., vol. 19, no. 1, pp. 54-65, Jan. 2004.

[2] P. Jose and N. Mohan, "A novel ZVS bidirectional Cuk converter for dualvoltage systems in automobiles," in Proc. 29th Annu. IEEE IECON, Nov. 2-6, 2003, vol. 1, pp. 117-122.

[3] M. Gang, Q. Wenlong, L. Yuanyuan, and L. Bin, "A novel soft switching bidirectional DC/DC converter," in Proc. ICEMS, 2005, vol. 2, pp. 1075-1079.

[4] W. Yu and J. S. Lai, "Ultra high efficiency bidirectional DC-DC converter with multi-frequency pulse width modulation," in Proc. IEEE APEC, 2008, pp. 1079-1084.

[5] J. Wang, F. Z. Peng, J. Anderson, A. Joseph, and R. Buffenbarger, "Low cost fuel-cell converter system for residential power generation," IEEE Trans. Power Electron., vol. 19, no. 5, pp. 1315-1322, Sep. 2004.

[6] H. J. Chiu and L. W. Lin, "A bidirectional DC-DC converter for fuel cell electric vehicle driving system," IEEE Trans. Power Electron., vol. 21, no. 4, pp. 950-958, Jul. 2006.

[7] D. Xu, C. Zhao, and H. Fan, "A PWM plus phase-shift control bidirectional DC-DC converter," IEEE Trans. Power Electron., vol. 19, no. 3, pp. 666-675, May 2004.

[8] H. Xiao and S. Xie, "A ZVS bidirectional DC-DC converter with phaseshift plus PWM control scheme," IEEE Trans. Power Electron., vol. 23, no. 2, pp. 813-823, Mar. 2008.

[9] H. Li and F. Z. Peng, "Modeling of a new ZVS bi-directional dc-dc converter," IEEE Trans. Aerosp. Electron. Syst., vol. 40, no. 1, pp. 272- 283, Jan. 2004.

[10] H. L. Chan, K. W. E. Cheng, and D. Sutanto, "ZCS-ZVS bi-directional phase-shifted DC-DC converter with extended load range," Proc. Inst. Elect. Eng.-Elect. Power Appl., vol. 150, no. 3, pp. 269-277, May 2003.

[11] K. Jin and $X$. Ruan, "Zero-voltage-switching multi-resonant three-level converters," IEEE Trans. Ind. Electron., vol. 54, no. 3, pp. 1705-1715,Jun. 2007.

[12] J.-J. Lee and B.-H. Kwon, "DC-DC converter using a multiple-coupled inductor for low output voltages," IEEE Trans. Ind. Electron., vol. 54, no. 1, pp. 467-478, Feb. 2007.

[13] K.-H. Cheng, C.-F. Hsu, C.-M. Lin, T.-T. Lee, and C. $\mathrm{Li}$, "Fuzzy-neural sliding-mode control for DC-DC converters using asymmetric Gaussian membership functions," IEEE Trans. Ind. Electron., vol. 54, no. 3, pp. 1528-1536, Jun. 2007.

[14] R.-J. Wai, C.-Y. Lin, R.-Y. Duan, and Y.-R. Chang, "High-efficiency DC-DC converter with high voltage gain and reduced switch stress," IEEE Trans. Ind. Electron., vol. 54, no. 1, pp. 354-364, Feb. 2007.

[15] K. M. Cho,W. S. Oh, Y. T. Kim, and H. J. Kim, "A new switching strategy for pulse width modulation (PWM) power converters," IEEE Trans. Ind. Electron., vol. 54, no. 1, pp. 330-337, Feb. 2007.

[16] H. Li, F.-Z. Peng, and J. S. Lawler, "A natural ZVS medium-power bidirectional DC-DC converter with minimum number of devices," IEEE Trans. Ind. Appl., vol. 39, no. 2, pp. 525-535, Mar. 2003. 
[17] P. Jose and N. Mohan, "A novel ZVS bidirectional cuk converter for dual voltage systems in automobiles," in Proc. IEEE IECON Conf. Rec., 2003, pp. 117-122.

[18] R. Li, A. Pottharst, N. Frohleke, and J. Bocker, "Analysis and design of improved isolated full-bridge bidirectional DC-DC converter," in Proc. IEEE PESC Conf. Rec., 2004, pp. 521-526.

[19] L. Zhu, "A novel soft-commutating isolated boost full-bridge ZVS-PWM DC-DC converter for bidirectional high power applications," in Proc. IEEE PESC Conf. Rec., 2004, pp. 2141-2146.

[20] S. Inoue and H. Akagi, "A bidirectional isolated DC-DC converter as a core circuit of the next-generation medium-voltage power conversion system," IEEE Trans. Power Electron., vol. 22, no. 2, pp. 535-542, Mar.2007.

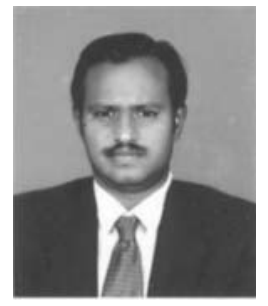

S.A.Elankurisil has obtained B.E degree from Madras university and M.E Degree from Sathyabama university in the years 1998 and 2006 respectively. He has ten years of teaching experience. $\mathrm{He}$ is presently a research scholar at sathyabama university. $\mathrm{He}$ is a life member of I.S.T.E.

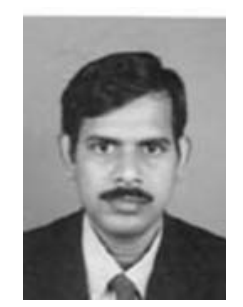

S.S.Dash is working as a Professor in SRM University, Chennai, India. He has 14 years of teaching and research experience. He has received ME Degree in power system Engineering from University College of Engineering, Burla, India, in the year of 1996. He obtained PhD degree in Electrical Engineering from Anna University in the year of 2006. His current research interests concern FACTS, Drives, Al techniques, Power System Operation and Power Electronics converters. 